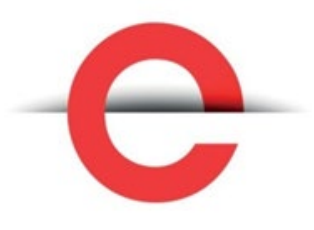

U T S

e PRE S S

\section{Cosmopolitan}

Civil Societies:

an

Interdisciplinary

Journal

Vol.11, No.2

2019

REFEREED PAPER

\title{
A Qualitative Study of the Interaction between Human Rights Defenders and Society in Russia: Assessing the Impact of the 'Foreign Agents' Law
}

\author{
Polina Malkova
}

Higher School of Economics, Moscow, Russian Federation

Corresponding author: Polina Malkova, Faculty of Law, Higher School of Economics, 109028 Moscow, 3 Bolshoy Trekhsvyatitelskiy pereulok, Russia. poli.malkova@gmail.com

DOI: http://dx.doi.org/10.5130/ccs.v11i2.6615

C) 2019 by the author(s). This is an Open Access article distributed under the terms of the Creative Commons Attribution 4.0 International (CC BY 4.0) License

(https://creativecommons.org/lic enses/by/4.0/), allowing third parties to copy and redistribute the material in any medium or format and to remix, transform, and build upon the material for any purpose, even commercially, provided the original work is properly cited and states its license.

Citation: Malkova, P. 2019. A qualitative study of the interaction between human rights defenders and society in Russia: Assessing the impact of the 'Foreign Agents' Law.

Cosmopolitan Civil

Societies: an Interdisciplinary Journal, 11:2, 1-20. https://doi.org/10.5130/ccs.v11.i $\underline{2.6615}$

ISSN 1837-5391 | Published by UTS ePRESS | https://mcs. epress.lib.uts.edu.au

Article History: Received 27/05/2019; Revised 01/08/2019; Accepted 09/09/2019;

Published 14/10/2019

\section{Abstract}

In various regions of the world, human rights defenders (HRDs) often become targets for smear campaigns that seek to discredit and marginalise them. Russia's 'foreign agents' law which brands NGOs as 'foreign agents' - a phrase that carries Soviet-era connotations of a spy or traitor - is just one example of states' attempts to cultivate an unfavorable image of rights defenders in society. Yet, despite the global context of such stigmatising campaigns and their potential to put defenders at further risk, there is very little systematic knowledge about the way citizens react to such rhetoric and whether they express more hostility towards HRDs. This paper seeks to address this gap and explores the interaction of rights defenders with the domestic society in Russia. Drawing upon in-depth interviews with representatives of the domestic human rights community, it demonstrates that while the wider public lacks familiarity with actors in the human rights field, certain social segments do interact with them, both in antagonistic and supportive ways. The paper argues that in the adverse conditions created by the 'foreign agents' law, there is a need for rights groups to expand and strengthen the links with their constituencies.

\section{Keywords}

Human Rights, Human Rights Defenders, 'Foreign Agents' Law, Civil Society in Russia 


\section{Introduction}

The law on 'foreign agents' adopted by the Russian Parliament in July 2012 has resulted in an unprecedented wave of repression for the domestic human rights community in the PostSoviet era and has subjected it to significant challenges. This law, officially titled 'On Amendments to Legislative Acts of the Russian Federation regarding the Regulation of the Activities of Non-profit Organizations Performing the Functions of Foreign Agents' (N 121FZ) ${ }^{1}$, required all non-governmental organizations (NGOs) that receive funding from abroad and engage in broadly defined 'political activities' to register with the Ministry of Justice as 'foreign agents'. Such organizations are also obliged to display this label on all their publications and follow detailed reporting requirements, with staggering fines following noncompliance.

The law's central term 'foreign agent' lacks neutrality. For the Russian public, it raises deeprooted and disturbing associations with Stalinist purges during the 1930s - early 1950s, when anyone who had a mere contact with a foreigner could be seen as an agent of intelligence services and be liable for arrest and punishment (Chandler 1998, p.76). As opinion polls demonstrate, for the majority of Russians this term still carries strong connotations of a 'spy' or 'traitor' (Levada 2016).

While scholars and practitioners note that Russia's example has served to inspire a larger backlash against foreign aid and democracy assistance (Gerber 2017, p. 317, Hooper and Frolov 2016; Mendelson 2015), obstacles to human rights work are indeed a rising global phenomenon. Efforts to increase governmental control of NGOs and their sources of funding can be observed in countries as diverse as China, Cambodia, Egypt, Israel and Hungary. In this context, 'foreign agent' allegations or appeals to sovereignty and national pride have become pervasive (Wolf 2005).

The question of the public's response to such rhetoric requires detailed empirical exploration. Scholars highlight the importance of favorable public opinion for NGO efficacy and survival (Ron et al. 2017). Furthermore, favorable public opinion can help Human Rights Defenders (HRDs) mobilize public support to survive state repression. In fact, public advocacy and grassroots mobilization in solidarity with rights defenders at risk are at the core of many HRD protective mechanisms, including petitions, support networks and Urgent Actions. However, despite the importance of the role that society can play for HRD security, the interaction between HRDs and the domestic public remains unexplored. What place do rights groups occupy in a given society? Do they experience public hostility and, if so, how do they cope with it? How does the interaction with key social segments affect their work, efficiency and security? Do laws such as the Russian 'foreign agents' law redefine the relationships between rights defenders and their constituencies?

Drawing upon in-depth quantitative interviews with the representatives of the Russian human rights community, this research aims to address these questions and understand how rights

\footnotetext{
${ }^{1}$ The Federal Law On Making Amendments to Certain Legislative Acts of the Russian Federation Regarding the Regulation of Activities of Non-Profit Organizations Performing the Functions of Foreign Agents from July 20, 2012, № 121-FZ.
} 
groups' interaction with society shapes their security and protection. Following the flow of the interviews, this paper outlines HRDs' experiences and perspectives in general and, more specifically, in the context of the challenging normative and political environment created by the 'foreign aid' legislation. The paper argues that in the adverse conditions created by this legislation, there is a need for rights groups to expand and strengthen the links with their constituencies.

\section{Perception of human rights NGOs by the Russian public}

Following the collapse of the Soviet Union and the subsequent profound political and economic crisis, numerous human rights and social organizations emerged in order to substitute for the responsibilities of the collapsed state and provide the population with basic need services. Yet, decades of 'forced volunteering' in various communist organizations have led to reluctance on the part of many citizens to join or support any organized groups or collectives. People generally viewed third sector organizations with mistrust and suspicion (Richter 2002). They tended to avoid the public sphere and instead relied on private, informal networks of family and friends in case they needed help (Evans 2015). As Henderson (2010, p. 261) writes, during the 1990s, 'many viewed NGOs with hostility, mistrust, or, at best, indifference'. Scholars note that the legacy of the Soviet Union continues to shape the civil society and still lingers in the propensity of Russians to engage with civic organizations and social movements (Crotty 2009).

Since the early 2000s, stigmatizing anti-NGO rhetoric has become prominent on an official level. Officials first raised concerns that Russian NGOs are merely serving the interests of foreign donors, while not paying sufficient attention to society's most acute needs (Putin 2004). State-owned media upheld this rhetoric and branded HRDs as 'fighting against the traditions of Russian statehood' (Lipman 2005). Since 2006, legislation introducing additional registration requirements for NGOs began to emerge ${ }^{2}$, largely as a response to 'Color revolutions' and a global pushback against international democracy assistance. The 2012 'foreign agents' law marked the peak of the efforts to discredit NGOs and their funding sources. Furthermore, the 2015 'undesirable organizations' law ${ }^{3}$ targeted and effectively banned foreign aid donors within the country.

What impact can these measures and rhetoric have on public perception of rights groups? Russian national public opinion polls do not offer a precise answer, yet, they demonstrate a lack of citizens' familiarity with NGOs. According to the Levada Center survey, the majority of Russians ( 52 percent) are not well-informed of NGOs' activities: 16 percent have a very general understanding of what NGOs do, while 29 percent have never heard of them (Levada 2013). Another survey demonstrates that 24 percent of respondents are not familiar with any non-commercial organization; out of the informed respondents, 37 percent reported trust to at least some kind of non-commercial organization, with unions for the protection of

${ }^{2}$ Federal Law on Introducing Amendments to Certain Legislative Acts of the Russian Federation No 18-FZ, 2006

${ }^{3}$ Federal Law on Introducing Amendments to Certain Legislative Acts of the Russian Federation No. 129-FZ of 23 May 2015. 
consumers' rights (12 percent) veterans' unions (9 percent) and trade unions ( 8 percent) being most trusted third-sector organizations (the Russian Higher School of Economics 2015).

Studies on public attitudes towards foreign funding of NGOs paint a rather unclear picture. As Gerber's research shows, Russians are indifferent to foreign funding, even if organizations' activity is expressly political (Gerber 2016). On the contrary, the 2016 Levada Center survey demonstrates that respondents are largely suspicious of NGO foreign funding and believe that it aims to harm the country, while only 13 percent think that foreign donors help resolve social problems in Russia. 49 percent of Russians approve of measures and laws that require NGOs to brand their materials as 'belonging to foreign agents' (Levada 2013). While Russians theoretically support measures that aim to control foreign funded NGOs, at the same time, the overwhelming majority ( 73 percent) has never heard of the 'foreign agents' law (Levada 2016).

Furthermore, an article by Asmik Novikova (2006) based on interviews with experts from various fields provides some insights regarding the position of human rights defenders in society. It demonstrates that suspicions in relation to rights defenders exist among Russians, including those related to NGO financing.

The available data and the existing legislative environment may suggest that Russian citizens have largely embraced the anti-HRD rhetoric and that rights activists are likely to experience high levels of public hostility. This paper aims to explore the firsthand accounts of the representatives of the human rights community and provide an understanding of how they experience social attitudes towards themselves and interact with society.

\section{Data and methods}

This study uses a qualitative research design and is based on interviews with human rights defenders working for human rights NGOs in Russia. Qualitative methods of data collection and analysis were chosen as they allow the researcher to gain a deeper understanding of complex phenomena (Creswell and Clark 2011). Interviews provide a way of obtaining information from participants and exploring their views, emotions, and lived experiences as well as the way they interpret these experiences (ibid). This approach allows the production of new knowledge and unique insights into an area with limited research.

In order to conduct interviews with rights defenders, the author reached out to key Russian human rights NGOs in person or via email. The author's position as a volunteer at a major Moscow-based NGO was helpful for identifying participants and establishing contact with them; it also facilitated building trust and rapport. The main fieldwork was conducted in Spring 2016 and follow-up interviews were conducted in Spring 2017.

Only NGOs working in the sphere of human rights were included in the sample. In order to select the participants, purposive sampling was used, which allows the interviewees to be identified according to key characteristics. The sampling was based on the author's estimations of whether interview participants would provide information that is of interest and relevance to the research questions. In particular, the author considered whether an 
organization had been included in the register of 'foreign agents'. Organizations and their leaders, whose stories and cases were especially important and appeared in the media, were of particular interest. Furthermore, snowball sampling was used when some respondents referred the author to other participants similar to them.

The limitation of the sampling was its inequality in terms of geographical location: the research mostly addressed the situation with Moscow-based NGOs. The author has not been able to reach out and explore very thoroughly the situation in the regions: traveling to other cities was difficult due to resource constraints. Although the author managed to contact HRDs from Russia's various cities and regions via email, the number of such interviews was lower than the number of interviews carried out within Moscow, where the researcher was based during the empirical research. Not only were almost all of the interviews with defenders from outside of Moscow conducted via email, but also the email interviews were typically not as detailed as face-to-face interviews and mostly did not include follow-up questions. Some informants provided limited information, for instance, those that were contacted during the ongoing harassment in relation to the 'foreign agents' law and were facing uncertainty.

Steps were taken to ensure that data was collected ethically. All the interviews were conducted by the author who ensured that participants were fully informed about the purpose of the research and that their participation was voluntary. Considering the sensitive nature of the research project and the actual or potential obstacles and risk involved in HRDs' work, the author undertook additional steps to ensure their anonymity. Due to the sensitivity of the study, written consent was not obtained in order to avoid leaving traces or signatures. However, participants provided verbal consent to participation. In order to ensure the observation of ethical procedures, before fieldwork was undertaken, the summary of the planned qualitative empirical study and the explanation of ethics-related procedures was submitted to and approved by the Ethics Board of the Chinese University of Hong Kong.

Each interview ranged in length between 30 and 80 minutes. Semi-structured interviews followed an interview guide to direct the discussions but allowed for flexibility of the conversation to explore the key emerging themes. The interview guide included questions regarding the ways rights defenders feel and experience social attitudes towards themselves in general, the ways they interact with the society in the context of the 'foreign agents' law and the existing challenges in their interaction and outreach to the wider public.

The interviews were recorded using a digital voice recorder. They were conducted and transcribed in Russian, and the transcripts were translated into English. Thematic analysis was used to analyze the data, which involved identifying the common ideas or themes that emerged from the interview data. First, open coding was used to identify specific themes that re-occurred across the discussions. Further, axial coding identified relationships between the initial open codes. The more specific axial codes helped to develop core categories and allowed concepts with similar characteristics to be grouped into subcategories; the emerging codes were then analyzed using the method of interpretive description. 


\section{Results}

Perception of HRDs by the Russian public: '[w]e live in parallel'

Most NGO representatives spoke about their interaction with the public specifically in the context of the 'foreign agents' law. The challenges posed by the law were particularly acute at the time when the interviews were being conducted and most interviewees focused on their experiences and perspectives in the context of this law.

The author first asked HRDs: 'As human rights defenders, do you feel and experience any attitudes towards yourself from the Russian society?'. Being asked this question, some participants first posed a counter-question: 'And what is the "society"?' and gave their understanding of this notion. Many participants did not view it holistically but distinguished two separate categories: the social majority and a thin stratum of civically engaged citizens. As the participants held:

"There is "society" that only expects to receive help and approaches HRDs when all other methods have failed. [...] And there is "society" that is ready to participate, to be engaged... .' (Director, NGO12 working on historical memory and human rights)

'In Russia, there are no structures that can be called "a society", they simply don't exist, there are no social ties. People press a TV button and that's it. We can only talk about ten percent of those who are civically active'. (Director, NGO9 working on soldiers' rights)

Thus, in terms of interaction with them, NGO representatives distinguished a small civically active stratum that engages with their initiatives and the social majority, which remains passive and influenced by propaganda. In view of many HRDs, the wider Russian public simply does not know about them and their work. Given this lack of awareness, people do not display any attitudes towards them. As one participant noted:

'What kind of attitude do people have towards us? We live in parallel. They don't have any attitude towards us. I don't think that someone loves or hates us. They simply don't know about our existence'. (Director, NGO16 working on applications to the ECHR)

This view was echoed by other participants: 'People do not know about HRDs' (Director, NGO2) and 'the majority of the population - those who do not face any human rights problems, those who agree with everything - don't need anything at all' (Director, NGO9 working on soldiers' rights).

Yet, the respondents further developed this thought: the lack of awareness and interest among the population remains only 'until something happens' - until people experience rights violations. Yet, even in this case turning to HRDs is seen as a last resort of limited success:

'But when something happens, people start searching - where shall we go, where shall we run? State bodies kick them out. They try something else; they are kicked out again. Then someone tells them: 'Why are you struggling here? Just call or write to an NGO'. (Director, NGO9 working on soldiers' rights) 
Several participants expressed an idea that when people turn to them as a last resort, commonly, they do so with a distorted perception of HRDs and their work. HRDs are often seen as 'free lawyers or honest civil servants [...] who strive in courts for people's interests and whose obligation is to take care of the people' (Director, NGO12, historical and human rights-oriented). As this participant explained,

'Of course, HRDs provide help for free and often provide legal help. But we are not free lawyers or civil servants who help to deal with bureaucratic issues: we are those who give you tools to defend your rights. And because these expectations do not coincide with our real mission, we are often perceived as "bad ones" as we don't perform our duties and don't take care of the people's interests'.

Rights defenders had a feeling that people often approach them in a very pragmatic manner. The following quote captures their overall sentiment:

'For the people, we are yet another option to try when dealing with the bureaucracy'. (Lawyer, NGO3, multi-profile)

Furthermore, more than one NGO representative pointed out that people often approach them with inappropriate, non-human rights claims divorced from their real mission. As the Head of the European Court of Human Rights-oriented NGO said:

'People approach us with all sorts of issues: their neighbors flooded them, a local governor is not performing his duties, their grandfather's property was confiscated during the Soviet times... But it's not our problem and not a problem of the European Court. We are unable to resolve it: the European Convention protects only a concrete set of rights. When we didn't have an ID check point, many people came here, even saying 'I have no place to sleep tonight'. (Director, NGO16 working on applications to the ECHR).

That these NGOs are often approached with non-human rights claims was echoed by another participant, who described that "an old grandma" can make a long trip to their organization claiming she had been overcharged for municipal services. Despite the fact that this issue is not this organization's area of work, they would, of course, 'help her to re-count those coins' [so that she can claim back the overcharged amount]. However, the defender noted that it is not their task, they 'have a broader mission, and such cases distract them from it' (Presssecretary, NGO5, multi-profile).

Apart from indifference and unfamiliarity with their work, HRDs also mentioned sensing negative and suspicious attitudes from the general public. Interestingly, several participants held that two contradictory perceptions may coexist in the public mind: both the compelling idea that foreign funded NGOs are 'agents of foreign influence' and the warm feelings towards the NGO that has helped them.

'There are a lot of funny stories, but in a sad way... A person receives help for free and then says something about foreign agents. Something like: 'You are so good, if only you maintained good relationships with the government and 
stopped receiving foreign grants!' Or something like: 'I don't trust NGOs, but specifically your NGO is good'. And the organization responds to him: 'Of course we are good - why are we able to help you for free? Because this lawyer receives a salary from a foreign grant'. (Director, NG012, historical and humanrights oriented)

'I hear conversations about "foreign agents" and "the US influence' from people waiting in line when they come to us for help". (Director, NGO11 working on refugee rights)

This kind of coexistence of opposing beliefs in the public mind suggests that people are unlikely to abandon their suspicions that human rights NGOs are 'saboteurs and agents of foreign influence' even after receiving help from them. Two contradictory viewpoints coexist, and the strongly-held anti-NGO beliefs do not preclude people from turning to HRDs for redress of their violated rights.

\section{HRDs' experiences of public hostility and support}

Online: 'constant abuse and disgrace'

The most immediate reaction of many interviewees was to mention hate comments online: 'upon each publication we make, there is constant abuse and disgrace' (NGO14, multiprofile); 'immediately after we post a video with the director of our NGO, we see these [derogatory] comments' (Lawyer, NGO1, multi-profile). Such comments mostly accuse rights activists of 'blackening Russia and trying to lower the authority of the government'. As one participant noted:

'When we made a publication on our website about the case involving incompetence of the police [regarding the migrants' rights] we got a lot of comments: 'You scold Russia. Stop writing nasty things about the country'. But who is saying bad things about the country?' (Director, NGO11 working on refugee rights)

Yet, many participants were uncertain whether hate comments reflected genuine opinions of members of society or were left by 'Internet trolls' - anonymous groups paid by the government in order to target Internet users and spread misinformation.

'Is it society? Or are they "trolls" working for money? [...] It's difficult to tell.

Oftentimes, we can't say: "It's all done by the trolls." There is a suspicion, but I can't say for sure. An atmosphere of abuse and hatred on the Internet is created around us, but who is spreading it? - who knows?' (Director, NGO12 working on historical memory and human rights)

'I have an impression that they are partly "trolls", partly not.'(Lawyer, NGO1, Multi-profile)

Interesting discussion arose on HRDs' reaction to hate comments. Defenders said they were 'too busy to look at them' (Director, NGO19 working on freedom of press) and did not feel insulted by such comments as they understood that either trolls or ideologically hostile 
individuals leave them. Yet, the Director of NGO11 working on refugee rights described her experience which demonstrates the importance of reacting to such comments:

'Sometimes I react to such comments. If it's just swearing, I delete them. But if it's something that gives an opportunity for discussion, I respond. Because people need to be talked to. Sometimes someone writes terrible things and then says: "I've looked at your website, now I have a very positive opinion of you". I say: "Well, very good, join us as a volunteer".' (Director, NGO11 working on refugee rights)

The quote above suggests that sufficient information can produce changes in individuals' view of human rights issues. In some cases, those who exhibit an antagonistic view of HRDs can be more susceptible to their message at least due to their interest in rights groups. As this participants' account demonstrates, in the process of attitude change her direct communication with people was important in giving them a clearer picture of her human rights work and replacing their negative stereotypes.

The numerous anti-HRD comments, however, do reach one major effect: they make any open discussion of human rights issues impossible among Internet users, thus creating additional obstacles for HRDs to promote their message:

'Even online, there is no platform for discussion, there can't be any good independent debate. If it is not a closed community, but an open one. These 'trolls' who interfere, they immediately destroy everything. It's impossible'. (Director, NGO12 working on historical memory and human rights).

\section{Hostility offline: provocations and misunderstanding}

The participants' experiences of hostility from certain social segments are not limited to the online sphere, but extend to real-world settings. HRDs mentioned facing various kinds of provocations and acts of hooliganism on the part of pro-government conservative groups, such as throwing eggs at them during press-conferences (Lawyer, NGO2, multi-profile), threatening messages left at their homes and offices (NGO7, multi-profile) and pickets at the doors of their organizations (NGO14, multi-profile).

One participant explained:

'From time to time, we face provocations, such as splashing water or zelyonka [green color liquid antiseptics] on us. We've also experienced several pickets at the doors of our organization by a group of young people who regularly "troll" human rights activists and the democratic opposition'. (PR Specialist, NGO17, multi-profile)

Another participant (Press-Secretary, NGO12 working on historical memory and human rights) provided a similar account and said that when their NGO was holding an exhibition on the Chechen war, a pro-government group NOD [National Liberation Movement] picketed their organization for three days 'with flags and posters'. Similarly, Orthodox activists held a picket during the NGO's exhibition on LGBTI rights. The interviewee further noted that 
'these are rare, out of the common episodes. Unlike our work, they are covered by the media with great enthusiasm'.

HRDs also mentioned misunderstanding from their family members. One defender working on prisoners' rights said:

'[w]e don't talk with my elder brother. Because if we start talking, the topic changes to politics, to my work. So we just stopped communicating at all'.

(Director, NGO20 working on prisoners' rights)

A similar account came from the lawyer of the prisoners' rights division of NGO2. She explained that she used to face misunderstanding from her family when she began her work and 'felt some negativity even from her closest relatives' - her mother and sisters, who were convinced criminals and serious offenders are not worth being defended. However, her stories and concrete examples of the injustice suffered by the detainees gradually enhanced their awareness of the issue and countered their prejudiced attitudes. She said that her relatives changed their attitude towards her job and now they perceive it as necessary. The participant noted:

'When you describe concrete cases, people's minds broaden. If before that they had a very limited understanding, now it's completely different. Now they realize that it's a very serious problem.'

An important part of the process of attitude change was this lawyer's communication with her family members and specifically, through the description of stories from her practice. Evidence delivered through vivid examples has been persuasive enough to transform their opposing attitudes to more supportive ones.

\section{Support from society}

The interviewees described a variety of ways in which their organizations received support, including gratitude from their clients, gifts, volunteer labor, material donations and other kinds of donations and support. Yet, they generally assessed public support of the human rights movement as rather weak. The Director of NGO12 noted that 'undoubtedly, such support is valuable' and 'everyone wants more [of it]', but it is insufficient given the degree of obstacles NGOs face: '[h]onestly, I don't see such a strong and active support of NGOs. In my opinion, all this is not enough'. Yet, the respondents mostly discussed public support in the context of the 'foreign agents' law.

\section{The effect of the 'foreign agents' law on HRD-society interaction}

Has the law affected general public's attitudes towards HRDs?

One of the participants [Director, NGO2] gave a rather clear answer to the question of whether, and to what extent, the 'foreign agents' law affected public attitudes towards rights groups. He suggested that this effect had not been significant as the social majority is unaware of the law; people will continue turn to rights groups as a last resort. At the same time, the law did not produce any changes among politically-savvy segments: it only reenforced the existing anti-HRD moods, while the more liberal segments understand the law's 
real purposes. Yet, the interviewee pointed out that it may have led to an increase of hostility among some politically undecided social groups.

Another interviewee echoed this, stating:

'The major campaign to discredit HRDs has not happened. It didn't appear in the major channels of communication. But if the government really needs it, it can do it overnight'. (Press-secretary, NGO1, multi-profile)

\section{Cooperation with partners: 'it was just cut off'}

While HRDs sensed that the 'foreign agents' law had not reached the wider public to cause any significant shifts in public attitudes towards them, they mentioned that this label had a chilling effect on some social segments and, in particular, complicated their interaction with key domestic stakeholders. The Head of the NGO working on refugee rights (NGO11) described how their long-standing partners from the domestic business sector suddenly refused to provide them with a grant, which 'had been approved and almost settled'. The interviewee concluded that their partners 'used to be their friends' but refused to cooperate because of the 'foreign agents' law. Second, the interviewee provided an example of a formal and cold response from their other partner, an organization of professional lawyers. When the interviewee's NGO was publishing a book on the rights of refugees and asked their partners to provide information on the number of their successful cases on refugee rights, the lawyers responded with a formal refusal to be mentioned in the NGO's book. The unfriendly response surprised and upset the NGO representatives, as they 'were talking to friends'. In the opinion of the respondent, this reaction was due to the 'foreign agent' status

This situation of former partners becoming unwilling to cooperate was also brought up by the Director of the NGO working on adaptation of refugees' children (NGO33). The interviewee said that in February 2016, the Moscow municipal authorities terminated the office rental agreement with them, despite the fact that the organization had been occupying their premises for many years. The interviewee was convinced that these sudden changes were triggered exactly by the 'foreign agents' law. A similar comment on this issue came from the representative of a NGO working on freedom of press:

'Our organization previously held a School of Investigative Journalists. It went with great demand and success. Even state structures thanked us. It was useful both for them and for us. But after this law it was just cut off. We had cases when seminars were cancelled without notification, two days before the event'.

(Director, NGO19).

As the quotes demonstrate, HRDs expressed frustration with their former partners, including business and donor organizations, municipal authorities and government officials who started to avoid talking to or working with those designated as foreign agents. It also shows that the law creates barriers for NGOs to connect to the broader public as it has reduced their ability to communicate their message to the broader public. 
Support in the context of the 'foreign agents' law: 'we have to strongly realize the value of this help'

The 'foreign agents' law entered into force in November 2012, and many organizations were at first boycotting it and refusing to register under its stigmatizing label. They called it 'slanderous' and 'unjust', and Russia's Ombudsman challenged it in the Constitutional Court, without any positive response (Oleinikova 2017). Since March 2013 hundreds of organizations across Russia were subjected to an unprecedented wave of inspections, followed by warnings, administrative cases and staggering fines for non-compliance. The campaign even involved a criminal case initiated in June 2016 against a HRD, named V. Cherevatenko (Front Line Defenders 2017a). Many NGOs received staggering fines equivalent up to $\$ 10,000$ USD. Short of funds to pay off the escalating fines, some NGOs faced the prospect of liquidation and reached out to their fellow citizens to raise the money. Repeatedly, NGO representatives affirmed the importance of domestic supporters in the face of the growing government interference. According to the interviewees' explanations, this was the most tangible indicator of societal support of the human rights sector:

'One of the most tangible forms of public support were the funds collected to pay the fines. In our case it was 600,000 rubles'. (Member of staff, NGO14, multiprofile)

'If we measure our support base by something tangible, it's when we gathered funds to pay off the fines levied against us. We didn't expect to gather the whole sum, but there was a real risk that we would be shut down. So, eventually, we asked people for help. Which other options did we have? We did not have any. We didn't get any institutional support in this case. So we have to strongly realize the value of this help'. (Press-Secretary, NGO12, multi-profile)

The interviewee explained that they appealed for help, including through a video, on their website and social media and eventually gathered the sum equivalent to $\$ 11,000$ USD to pay off the fine. She also noted that their organization held a series of concerts and poetry readings, which also helped gather donations. Similar accounts came from other participants (NGO2, NGO4, NGO7, NGO12) who explained that they managed to gather money from businessmen and private donations, which helped ensure their organizations' survival. The interviewees mentioned that the donations came from a variety of domestic sources - private foundations, businesses and 'not indifferent citizens', including, for instance, the Teachers' Union.

Overall, the challenges brought by the 'foreign agents' law show the tangible and practical value of societal support that helped ensure NGOs' continued existence. Turning to their domestic constituents has been one of the key survival strategies used by organizations charged with high administrative fines.

Furthermore, the HRD who faced criminal prosecution for non-compliance with the law affirmed the importance of such support. She provided the following comment:

'The criminal case against me is a separate story. Local journalists reacted to this: some with curiosity, some with alertness and some with support. But there 
were no negative publications in the print media of our city and in the region.

Publications that supported me, undoubtedly, helped, and I am grateful for that'.

Thus, the defender noted that the positive media attention helped her during tough times of criminal prosecution. While it is difficult to quantitatively measure the cause and effect relationship between publicity and the increased political costs of targeting of HRDs, it can be assumed that the expressions of solidarity and public resonance fostered an atmosphere of scrutiny and thus contributed to the closure of the criminal case in July 2017 (Front Line Defenders 2017b).

Increased social outreach: 'it made us seriously re-think and invest in public relations' Importantly, some interviewees held that the new difficult conditions for conducting human rights work made them re-evaluate their communication strategies and increase their social outreach. One NGO representative (NGO17) said that the new legislation did not lead to increased social hostility, but on the contrary, increased public awareness and revealed the positive attitudes towards their organization:

'The media provided strong support of our NGO within the region. In addition, the Ombudsman and the Governor spoke in support of our organization [being] recognized as a 'foreign agent' in the Center for the Protection of Media Rights. After the adoption of the law [on 'foreign agents'], prosecutorial checks began and journalists were very worried about our fate. Several times, they published articles about the work of our legal advice clinics and our lawyers'.

This interviewee further added that the law did not lead to increased social hostility, but on the opposite, increased public awareness and revealed the positive attitudes towards their organization.

'It [the 'foreign agents' law] made us seriously re-think and invest in public relations and explore new avenues of intersectoral communication. In the autumn of 2016, we launched an award program to celebrate those who contribute to the social life of our city and region. At the ceremony, many guests said that they didn't know we existed and were happy to meet and get to know us'.

A similar account was observed in the interview by another participant.

'Overall, the level of negativity towards our organization has not changed after this law - in some cases it even decreased, thanks to our active work and public relations projects'. (Head of regional branch, NGO10, working on soldiers' rights)

The HRD further explained that their NGO did not have enough funding for the educational webinars after it had chosen to stop receiving foreign funding. In order to continue this program, it used a crowdfunding platform. The NGO leader said:

'Classical funding scheme has spoiled us. We were entrenched in the idea that not the citizens, but someone else has to pay for our work. [...] We decided to attract private donations not only in emergency situations, but also for our dayto-day work. To some extent, the general background of mistrust to foreign 
funded organizations and the campaign launched against NGOs in the summer of 2014 has contributed to this and led to drastic changes in our fundraising strategy'.

Furthermore, the organization working on adaptation of refugees' children (NGO33) noted its reliance on volunteers after it stopped receiving (foreign) funding. The Director noted: 'We only rely on our volunteers to sustain ourselves. We would like to broaden the pool of volunteers now. Only our Director and Coordinator receive salaries. The rest is volunteer work'.

Thus, in many NGOs' experience, the 'foreign agent' label has not led to an increase in negative social attitudes, but on the contrary, encouraged organizations to invest in public relations campaigns and enlarge their social base. For many, private donations and volunteer work started to serve as a key resource to replace foreign grants. The participants' accounts demonstrate that the increasing political and legal restrictions on foreign funding forced them to work more actively on their public reputation and innovate fundraising strategies that engage ordinary Russian citizens.

\section{Discussion}

Generally, the empirical data derived from the interviews with NGO representatives reveal a deep disconnection between the human rights movement and the vast majority of Russian citizens. According to HRDs, the public 'lives in parallel' with them and does not hold or display any attitudes towards them. This is consistent with scholarly commentary that many Russians consider rights-based approaches to be of limited success and view them as timeconsuming, stressful and unproductive (Turbine 2007). Furthermore, while people may turn to HRDs for help, they often do so with issues that are divorced from NGOs' real missions or even from the arena of human rights. A lack of understanding of the nature of HRDs' role exists, which often leads to a public perception of rights groups as 'useless'.

Highlighting the information gap between the human rights sector and ordinary citizens, the representatives of the human rights movement felt that the 'foreign agents' law had not reached the masses and thus had not had any adverse effect on public attitudes towards them. These estimations are supported by quantitative data: the survey conducted by the polling center Levada (2016) reveals a lack of awareness about this law. In particular, it shows that the overwhelming 73 percent of Russians do not know anything about it, 20 percent have heard of it, while only 2-3 percent reported detailed awareness of it. Yet, some interviewees said that if the 'foreign agent' campaign had been more intensified and consistently appeared in the mass channels of communication, the masses would know more about it and would be likely to accept it without question.

Yet, the 'foreign agent' label has not gone unnoticed for HRD-society interaction. Our qualitative research demonstrates that it has led to an increase of negative attitudes among those social segments and stakeholders with whom HRDs interact more frequently. The designation as a 'foreign agent' resulted in antagonism towards NGOs on the part of businesses, municipal bodies and other partners. For many organizations, it has led to closure 
of educational and volunteering programs. Given that HRDs had already felt a lack of outlets and channels to disseminate their message, the barriers in their social outreach became even more pronounced.

On the other hand, the challenging legislative and political environment demonstrates the importance of public support. When staggering fines put NGOs onto the verge of liquidation, domestic support proved to be vital. Moreover, public action on behalf of HRDs is an important mechanism of HRD protection. The case of Ms Cherevatenko, who faced criminal charges for non-compliance with the 'foreign agents' law is in June 2016, is illustrative. The initiation of this case was followed by a wide campaign in solidarity with the defender, including human rights awards and national and international media attention. This public resonance fostered an atmosphere of scrutiny and solidarity and eventually, in July 2017, the case against the defender was closed.

Overall, can rights defenders expect to receive support from society, or do they face serious hostility? While HRDs do not experience much explicit aggression, the majority of Russians are unlikely to act in support of HRDs simply because they are unaware of any challenges facing the human rights movement. As for the more active social segments, they do interact with rights groups through different modes of engagement: from expressly hostile to collaborative ones. Yet, in cases of increased pressure, it seems that the potential threats stemming from some social segments are largely outweighed by the positive role of societal support due to its constructiveness in helping ensure NGOs' survival.

In the current environment, broadening their support base may be one of the key strategies to reduce NGOs' vulnerability to states' de-legitimization efforts (Wolf, 2005). In the age of severe foreign aid restrictions, this work is especially important. Scholars note that NGOs that rely exclusively on international financing are in a highly unsustainable position if they fail to diversify their sources of support (Sundstrom 2006). Yet, our research demonstrates that with the decline of external support, the civic sector in Russia began to catalyze efforts to strengthen alliances with their constituents. This finding supports the argument that the closing civic space phenomenon often correlates with organizations' heavy dependence on external financing and their weak ties with the local populations - with foreign aid in development sphere having a particularly negative impact (Medelson 2015, Raine 2006). As Raine (2006) notes, 'any organization that depends on a narrow number of donors and does not have a broad base of citizen support risks losing touch with the people whom it is trying to serve'.

In order to broaden their support base, it is important that activists themselves fundamentally trust their constituencies. Observers have noted that Russian activists are instead prone 'to suspicion of the people and contempt for their unenlightened state' (Rochowanski 2013, np). Our qualitative interviews demonstrate that while the participants did acknowledge the importance of support by some active social segments, they expressed a belief that the broader society views them with suspicion or indifference, and none of them mentioned that it might be positively inclined towards them. This finding may support the suggestion that activists themselves have little confidence in the public's ability to effectively participate in 
human rights and political affairs (Abrams and Auer 2004). Western observers have long noted that Russian activists 'rarely seemed to take citizen participation seriously' (Bell 2001, p. 12) and this kind of disdain prevents them from reaching out to their constituents for political as well as economic cooperation (Abrams and Auer 2004). Yet, HRDs' experiences demonstrate that their communication with the people, discussions and explanations about their work commonly led to changes in individuals' attitudes.

\section{Conclusion}

This paper presented the data from a large set of interviews with Russian national NGOs discussing the impact of the recent 'foreign aid' legislation and the wider context of their work. Generally, the 'foreign agents' law had severe consequences for NGOs and their efficiency. As Oleinikova (2017) observes, this legal environment had an overall cooling effect on the civil society; it has diminished the pluralism of civic initiatives, and numerous NGOs had to discontinue their work.

Yet, this crisis has also created incentives for rights groups to work more actively on bridging the gaps between them and the broader public and, in the longer term, to move from overseas funding to a public support base. Externally-funded NGOs can often become overly professionalized and elitist, and, in the process, separated from their constituencies. On the other hand, becoming more reliant on domestic funding and support can invigorate the public legitimacy of organizations. More broadly, this suggests that civil society participation is a politically reflexive process, as organizations may respond to political repression by publicfacing organizing strategies and activities. In turn, this can transform NGOs from expert advocacy organizations more into social movement NGOs with an active social base. It is hoped that this new environment will create more paths for rights groups to engage with ordinary Russians. The ways in which HRD-society interaction develops and is manifest with the time is a subject of further research and analysis.

\section{References}

Abrams, J. E. \& Auer, M. R. 2004, 'The disappearance of popular environmental activism in Post- Soviet Russia', in Auer, M. R. (Ed) Restoring Cursed Earth: Appraising Environmental Policy Reforms in Eastern Europe and Russia, Rowman \& Littlefield, Lanham, Chapter 6.

Bell, R. 2001, Reaching across the Communication Gulf: Reflections on the Challenges of Environmental Assistance Programmes. Discussion Paper 01-05, Washington DC: Resources for the Future.

Carothers, T. \& Brechenmacher, S. 2014, Closing Space. Democracy and Human Rights Support under Fire, Carnegie Endowment for International Peace, Washington, DC. Accessed 1 May 2019, https://carnegieendowment.org/files/closing_space.pdf

Chandler, A. 1998, Institutions of Isolation: Border Controls in the Soviet Union and Its Successor States, 1917-1993, McGill-Queen's University Press, Montreal.

Creswell, J. W. \&Plano Clark, V. L. 2011, Designing and Conducting Mixed Methods Research, (2nd ed.), SAGE Publications, Los Angeles.

Crotty, J. 2009, 'Making a difference? NGOs and civil society development in Russia', Europe-Asia Studies, vol.61, no.1, pp. 85-108. https://doi.org/10.1080/09668130802532936 
Evans, A. 2015, 'Civil society and protests in Russia', in Ross, C. (ed.) Systemic and NonSystemic Opposition in the Russian Federation: Civil Society Awakens?, Routledge, New York, pp. 15-34.

Front Line Defenders 2017a, Russia: Criminal case against Valentina Cherevatenko closed. Accessed 1 May 2019,https://www.frontlinedefenders.org/en/case/case-historyvalentina-cherevatenko.

Front Line Defenders 2017b, Valentina Cherevatenko, case history. Accessed 11 May 2019, https://www.frontlinedefenders.org/en/case/case-history-valentina-cherevatenko

Gerber, T. 2016, 'Grounds for (a little) optimism? Russian public opinion on human rights'. Accessed 11 May 2019, https://www.opendemocracy.net/openglobalrights/theodore-ogerber/grounds-forlittle-optimsm-russian-public-opinion-on-human-right

Henderson, S. 2010, 'Shaping civic advocacy: International and domestic policies toward Russia's NGO sector', in Prakash, A. and Gugerty, M. K. (eds.) Advocacy Organisations and Collective Action, Cambridge University Press, Cambridge, pp. 252-279. https://doi.org/10.1017/cbo9780511762635.014

Higher School of Economics 2015, Informational Bulletin on the state of civil society and non-commercial sector in Russia. Accessed 15 May 2019 https://www.hse.ru/data/2015/03/31/1095858158/Bulleten4 Web.pdf

Hooper, M. \& Frolov, G. 2016, Russia's Bad Example. Free Russia Foundation and Human Rights First. Accessed 15 May 2019,www.4freerussia.org/wpcontent/uploads/2016/Russias -Bad-Example.pdf

Levada Center, 2013, Russians' attitudes towards non-commercial organisations. Accessed 15 May 2019,https://www.levada.ru/2013/07/11/otnoshenie-k-nko/ (In Russian).

Levada Center. 2016, Attitudes towards the law on non-commercial organisations. Accessed 15 May 2019,http://www.levada.ru/2017/02/07/zakon-o-nekommercheskihorganizatsiyah/ (In Russian).

Lipman, M. 2005, How Russia Is not Ukraine: The Closing of Russian Civil Society, Carnegie Endowment for International Peace. Accessed 10 May 2019, https://carnegieendowment.org/files/PO8lipmanfinal.pdf

Mendelson, S. 2015, 'Why Governments Target Civil Society and What Can Be Done in Response; A New Agenda, A report of the CSIS Human Rights Initiative, Center for Strategic and International Studies, Washington, DC. Accessed 1 May 2019, https://www.csis.org/analysis/why-governments-target-civil-society-and-what-can-bedone-response

Novikova, A. 2006, 'Society on Human Rights Defenders' (in Russian) Monitoring Obshestvennogo Mnenija 79 (3): 47-56.

Oleinikova, O. 2017, 'Foreign funded NGOs in Russia, Belarus and Ukraine: Recent restrictions and implications', Cosmopolitan Civil Societies: an Interdisciplinary Journal, vol.9, no.3, pp. 85 -94. https://doi.org/10.5130/ccs.v9i3.5637

Putin, V. 2004, Poslanie Federal'nomyu Sobraniiu Rossijskoj Federacii. [A Note for the Federal Assembly of the Russian Federation], (Accessed 11 August 2018), http://kremlin.ru/events/president/transcripts/22494-

Raine, F. 2006,'The measurement challenge in human rights', Sur, Revista Internacional de Direitos Humanos, vol. 3, no. 4, pp. 6-29. https://doi.org/10.1590/s180664452006000100002

Rochowanski A. Funding Russian NGOs: opportunity in a crisis? 13 February 2013, Accessed 10 September 2019, https://www.opendemocracy.net/en/odr/fundingrussian-ngos-opportunity-in-crisis/

Ron, J., Golden, S., Crow, D. and Pandya, A. 2017, Taking Root: Human Rights and Public Opinion in the Global South. New York, NY: Oxford University Press. 
Sundstrom, L. M. 2006, Funding Civil Society; Foreign Assistance and NGO Development in Russia, Routledge, New York.

Turbine, V. 2007, 'Russian women's perceptions of human rights and rights-based approaches in everyday life', in Kay, R. (ed.) Equality and Difference During and After State Socialism, Palgrave Macmillan, New York.

Wolff, J. (2018) 'The delegitimization of civil society organisations: Thoughts on strategic responses to the 'foreign agent' charge', in Rodríguez-Garavito, C. and Gomez, K. (eds.), Rising to the Populist Challenge: A New Playbook for Human Rights Actors, Dejusticia, Bogota, pp.129-137. 


\section{Appendix 1 - List of Interviewees}

\begin{tabular}{|c|c|c|c|c|c|}
\hline $\begin{array}{l}\text { NGO ID } \\
\text { number }\end{array}$ & NGO profile & Interviewee & $\begin{array}{l}\text { Locatio } \\
\mathrm{n}\end{array}$ & $\begin{array}{l}\text { Type of } \\
\text { Interview }\end{array}$ & Date \\
\hline NGO1 & $\begin{array}{l}\text { Multi-Profile and } \\
\text { Coordinating Center } \\
\text { NGO }\end{array}$ & $\begin{array}{l}\text {-Director } \\
\text {-lawyer }\end{array}$ & Moscow & $\begin{array}{l}\text { Face-to- } \\
\text { face }\end{array}$ & $\begin{array}{l}3 \text { March } \\
2016 ; \\
\text { follow-up } \\
14 \text { March } \\
2017\end{array}$ \\
\hline NGO2 & $\begin{array}{l}\text { Moscow Office of a } \\
\text { NGO Network }\end{array}$ & $\begin{array}{l}\text {-Director } \\
\text {-lawyer } \\
\text {-PR specialist }\end{array}$ & Moscow & $\begin{array}{l}\text { Face-to- } \\
\text { face }\end{array}$ & $\begin{array}{l}24 \\
\text { February } \\
2016 ; \\
\text { Follow-up } \\
9 \text { March } \\
2017\end{array}$ \\
\hline NGO3 & $\begin{array}{l}\text { Kaluga Office of a } \\
\text { NGO Network }\end{array}$ & - Lawyer & Kaluga & E-mail & $\begin{array}{l}\text { 15 March } \\
2017\end{array}$ \\
\hline NGO4 & $\begin{array}{l}\text { Saratov Office of a } \\
\text { NGO Network }\end{array}$ & - Secretary & Saratov & E-mail & $\begin{array}{l}\text { 21 March } \\
2017\end{array}$ \\
\hline NGO5 & $\begin{array}{l}\text { Perm' Office of a NGO } \\
\text { Network }\end{array}$ & - Secretary & Perm' & E-mail & $\begin{array}{l}\text { 17 March } \\
2017\end{array}$ \\
\hline NGO6 & $\begin{array}{l}\text { Samara Office of a } \\
\text { NGO Network }\end{array}$ & $\begin{array}{l}\text {-position of interviewee not } \\
\text { identified }\end{array}$ & Samara & E-mail & $\begin{array}{l}16 \text { March } \\
2017\end{array}$ \\
\hline NGO7 & $\begin{array}{l}\text { Krasnoyarsk Office of } \\
\text { a NGO Network }\end{array}$ & $\begin{array}{l}\text {-position of interviewee not } \\
\text { identified }\end{array}$ & $\begin{array}{l}\text { Krasnoy } \\
\text { arsk }\end{array}$ & E-mail & $\begin{array}{l}\text { 21 March } \\
2017\end{array}$ \\
\hline NGO8 & $\begin{array}{l}\text { NGO working on } \\
\text { Soldiers' Rights } \\
\text { (branch) }\end{array}$ & $\begin{array}{l}\text {-Head } \\
\text {-Lawyer }\end{array}$ & Moscow & $\begin{array}{l}\text { Face-to- } \\
\text { face }\end{array}$ & $\begin{array}{l}\text { 16 March } \\
2016\end{array}$ \\
\hline NGO9 & $\begin{array}{l}\text { NGO working on } \\
\text { Soldiers' Rights (main } \\
\text { office) }\end{array}$ & -Head & Moscow & $\begin{array}{l}\text { Face-to- } \\
\text { face }\end{array}$ & $\begin{array}{l}17 \text { March } \\
2016\end{array}$ \\
\hline NGO10 & $\begin{array}{l}\text { Regional Branch of the } \\
\text { NGO working on } \\
\text { Soldiers' Rights }\end{array}$ & -Head & $\begin{array}{l}\text { St- } \\
\text { Petersbu } \\
\text { rg }\end{array}$ & E-mail & $\begin{array}{l}11 \text { April } \\
2016\end{array}$ \\
\hline NGO11 & $\begin{array}{l}\text { NGO working on } \\
\text { refugees' rights }\end{array}$ & -Head & Moscow & $\begin{array}{l}\text { Face-to- } \\
\text { face }\end{array}$ & $\begin{array}{l}14 \text { April } \\
2016\end{array}$ \\
\hline NGO12 & $\begin{array}{l}\text { Historical and Human } \\
\text { Rights-oriented NGO }\end{array}$ & $\begin{array}{l}\text {-Director } \\
\text {-Press-Secretary } \\
\text {-Librarian } \\
\end{array}$ & Moscow & $\begin{array}{l}\text { Face-to- } \\
\text { face }\end{array}$ & $\begin{array}{l}20 \text { April } \\
2016\end{array}$ \\
\hline NGO13 & $\begin{array}{l}\text { NGO working on } \\
\text { deceased soldiers' } \\
\text { families' rights }\end{array}$ & -Press-Secretary & Moscow & $\begin{array}{l}\text { Face-to- } \\
\text { face }\end{array}$ & $\begin{array}{l}29 \text { April } \\
2016\end{array}$ \\
\hline NGO14 & $\begin{array}{l}\text { Regional multi-profile } \\
\text { NGO }\end{array}$ & $\begin{array}{l}\text {-Position of interviewee not } \\
\text { identified }\end{array}$ & Bryank & E-mail & $\begin{array}{l}18 \text { April } \\
2016\end{array}$ \\
\hline NGO15 & $\begin{array}{l}\text { Major multi-profile and } \\
\text { history-oriented NGO }\end{array}$ & $\begin{array}{l}\text {-Executive Director } \\
\text {-Secretary }\end{array}$ & Moscow & $\begin{array}{l}\text { Face-to- } \\
\text { face }\end{array}$ & $\begin{array}{l}\text { 19 April } \\
2016 ; \\
\text { Follow-up } \\
10 \text { March } \\
2017 .\end{array}$ \\
\hline NGO16 & ECHR-oriented NGO & - Head & Moscow & $\begin{array}{l}\text { Face-to- } \\
\text { face }\end{array}$ & $\begin{array}{l}\text { 22April } \\
2016\end{array}$ \\
\hline
\end{tabular}




\begin{tabular}{|c|c|c|c|c|c|}
\hline NGO17 & $\begin{array}{l}\text { Regional Human } \\
\text { Rights Center and Hub }\end{array}$ & - PR-Specialist & $\begin{array}{l}\text { Voronez } \\
\mathrm{h}\end{array}$ & E-mail & $\begin{array}{l}16 \text { March } \\
2017\end{array}$ \\
\hline NGO18 & $\begin{array}{l}\text { Organisation working } \\
\text { on violations by the } \\
\text { police }\end{array}$ & $\begin{array}{l}\text { - Public relations specialist } \\
\text {-Lawyer }\end{array}$ & Moscow & $\begin{array}{l}\text { Face-to- } \\
\text { face }\end{array}$ & $\begin{array}{l}25 \text { April } \\
2017 ; \\
\text { Follow-up } \\
20 \text { March } \\
2017\end{array}$ \\
\hline NGO19 & $\begin{array}{l}\text { Foundation working on } \\
\text { Freedom of Press }\end{array}$ & -Head & Moscow & $\begin{array}{l}\text { Face-to- } \\
\text { face }\end{array}$ & $\begin{array}{l}26 \text { April } \\
2016\end{array}$ \\
\hline NGO20 & $\begin{array}{l}\text { Center working on } \\
\text { criminal justice and } \\
\text { prison reform }\end{array}$ & $\begin{array}{l}\text { - Director } \\
\text { - Assistant of the Director }\end{array}$ & Moscow & $\begin{array}{l}\text { Face-to- } \\
\text { face }\end{array}$ & $\begin{array}{l}\text { 11 April } \\
2016\end{array}$ \\
\hline NGO21 & $\begin{array}{l}\text { NGO working on } \\
\text { violations of rights by } \\
\text { psychiatric institutions }\end{array}$ & - Head & Moscow & $\begin{array}{l}\text { Face-to- } \\
\text { face }\end{array}$ & $\begin{array}{l}14 \text { April } \\
2016\end{array}$ \\
\hline NGO22 & $\begin{array}{l}\text { NGO working on } \\
\text { monitoring detentions } \\
\text { of those exercising } \\
\text { rights of freedom of } \\
\text { assembly and } \\
\text { expression }\end{array}$ & $\begin{array}{l}\text { - Coordinator } \\
\text { - Lawyer }\end{array}$ & Moscow & $\begin{array}{l}\text { Face-to- } \\
\text { face }\end{array}$ & $\begin{array}{l}27 \text { April } \\
2016 \\
\text { Follow-up } \\
5 \text { April } \\
2017 \\
\end{array}$ \\
\hline NGO23 & $\begin{array}{l}\text { NGO working on } \\
\text { Peace-building and } \\
\text { women's rights }\end{array}$ & - Head & $\begin{array}{l}\text { Rostov- } \\
\text { on-Don }\end{array}$ & E-mail & $\begin{array}{l}6 \text { April } \\
2017\end{array}$ \\
\hline NGO24 & $\begin{array}{l}\text { Regional multi-profile } \\
\text { and election- } \\
\text { monitoring NGO }\end{array}$ & - Coordinator & $\begin{array}{l}\text { St } \\
\text { Petersbu } \\
\text { rg }\end{array}$ & E-mail & $\begin{array}{l}17 \\
\text { February } \\
2016\end{array}$ \\
\hline NGO25 & $\begin{array}{l}\text { - Center working on } \\
\text { adaptation on refugees' } \\
\text { children }\end{array}$ & -Director & Moscow & $\begin{array}{l}\text { Face-to- } \\
\text { face }\end{array}$ & $\begin{array}{l}23 \text { March } \\
2017\end{array}$ \\
\hline
\end{tabular}

